\title{
Membran Padat Kitosan-Silika-PEG sebagai Membran Pemisah Ion Logam Bivalen dan Rhodamin B pada Limbah Cair Industri Tekstil
}

\author{
F. Widhi Mahatmanti ${ }^{1 *}$, E. Kusumastuti ${ }^{1}, \&$ W. D. P. Rengga ${ }^{2}$ \\ ${ }^{1}$ Jurusan Kimia, Fakultas Matematika dan Ilmu Pengetahuan Alam, Universitas Negeri Semarang, \\ Indonesia 50229 \\ ${ }^{2} J u r u s a n$ Teknik Kimia, Fakultas Teknik, Universitas Negeri Semarang, Indonesia 50229 \\ Corresponding author: widhimahatmanti17@gmail.com, fwidhi_kimia@mail.unnes.ac.id
}

\begin{abstract}
Article history
Received: $2^{\text {nd }}$ February 2020

2020

Accepted: $7^{\text {th }}$ June 2020

DOI:

\author{
Kata-kata kunci: \\ Membran pemisah \\ Membran padat $\mathrm{Ch} / \mathrm{Si} / \mathrm{P}$ \\ Ion logam bivalen \\ Rhodamin B
}

Received in revised form: $14^{\text {th }}$ May

10.17977/um0260v3i22019p012

\begin{abstract}
Abstrak
Penggunaan membran padat kitosan-silika-polietilen glikol $(\mathrm{Ch} / \mathrm{Si} / \mathrm{P})$ sebagai membran pemisah telah dipelajari. Dalam penelitian ini, membran padat kitosan-silika-polietilen glikol digunakan sebagai membran pemisah untuk ion logam bivalen, termasuk $\mathrm{Pb}$ (II), $\mathrm{Cu}$ (II), Cd II), dan zat warna Rhodamin B dalam limbah cair tekstil. Membran padat $\mathrm{Ch} / \mathrm{Si} / \mathrm{P}$ dibuat dengan mencampurkan kitosan, silika (dengan natrium silikat yang diisolasi dari abu sekam padi sebagai sumber silika) dan polietilen glikol dengan perbandingan 1: 0,8: 0,5 (b/b). Uji kinerja membran padat dilakukan menggunakan metode dead-end. Uji kinerja menunjukkan bahwa selektivitas membran padat $\mathrm{Ch} / \mathrm{Si} / \mathrm{P}$ meningkat dari $\mathrm{Cu}(\mathrm{II})>\mathrm{Cd}(\mathrm{II})>\mathrm{Pb}(\mathrm{II})>$ Rhodamine $\mathrm{B}$. Membran komersial menunjukkan, selektivitas mengikuti urutan Rhodamine $\mathrm{B}>\mathrm{Pb}$ (II) $>\mathrm{Cd}$ (II) $>\mathrm{Cu}$ (II). Hasil penelitian menunjukkan bahwa membran padat $\mathrm{Ch} / \mathrm{Si} / \mathrm{P}$ lebih baik sebagai membran pemisah ion logam bivalen dibandingkan membran komersial. Membran komersial lebih baik sebagai membran pemisah Rhodamine B dibandingkan membran padat $\mathrm{Ch} / \mathrm{Si} / \mathrm{P}$ karena memiliki struktur berserat dan berpori.
\end{abstract}

\begin{abstract}
The use of membrane on separation has been widely studied. In this study, the Chitosan-silicapolyethylene glycol $(\mathrm{Ch} / \mathrm{Si} / \mathrm{P})$ solid membrane is prepared and performed adsorption test for bivalent metal ions, including $\mathrm{Pb}(\mathrm{II}), \mathrm{Cu}(\mathrm{II})$, and $\mathrm{Cd}(\mathrm{II})$, and Rhodamine $\mathrm{B}$ dye in textile waste water. The Ch/Si/P composite membrane is made by mixing of chitosan, silica (extracted from ash hulk) and polyethylene glycol with ratio 1: 0.8: 0.5 (w/w). The performance of membrane is carried out using dead end method. The result shows that membrane has a heteregenous and very tight structure. On the other hand, commercial membrane shows a fibrous structure. The rejection test shows that the selectivity of Ch/Si/P solid membrane increases from $\mathrm{Cu}(\mathrm{II})>\mathrm{Cd}(\mathrm{II})>\mathrm{Pb}(\mathrm{II})>$ Rhodamine $\mathrm{B}$. In comparison, the commercial membrane shows the selectivity in the sequence of Rhodamine $\mathrm{B}>\mathrm{Pb}(\mathrm{II})>\mathrm{Cd}(\mathrm{II})>\mathrm{Cu}(\mathrm{II})$. It is clearly observed that $\mathrm{Ch} / \mathrm{Si} / \mathrm{P}$ solid membrane for bivalen metal ions is better than commercially available, and it indicates that functional group spread on the surface acts as a binding site.
\end{abstract}

\section{PENDAHULUAN}

Industri tekstil merupakan satu dari sekian kegiatan industri yang cukup berkembang di Indonesia. Salah satu yang perlu diperhatikan pada industri tekstil adalah limbah yang dihasilkan yang dapat mencemari lingkungan. Limbah industri tekstil tersebut akan mengalir langsung ke selokan atau ke sungai, sehingga limbah cair ini dapat menurunkan daya 
pembersih alam yang dimiliki air, dapat mengubah warna air sungai, bahkan dapat mengakibatkan matinya organisme air yang penting artinya bagi kehidupan manusia.

Limbah cair industri tekstil merupakan limbah yang dihasilkan dalam proses penghilangan kanji, pengelantangan, pemasakan, maserasi, pewarnaan, pencetakan dan proses penyempurnaan. Pewarnaan dan pembilasan menghasilkan air limbah yang berwarna dengan COD tinggi dan bahan-bahan lain dari zat warna yang dipakai seperti fenol dan berbagai macam ion logam. Limbah cair industri tekstil didominasi oleh pencemaran yang berupa zat warna akibat penggunaan zat warna baik yang alami maupun sintetis dalam proses produksinya. Zat warna yang sering dipakai dalam industri tekstil seperti sutera dan wool adalah zat warna Rhodamin B. Zat warna Rhodamin B merupakan zat warna basa (kation) yang umumnya merupakan garam-garam klorida atau oksalat dari basa-basa organik. Berdasarkan strukturnya zat warna ini dapat bersifat sebagai zwitter ion (bersifat asam maupun basa). Jenis ion logam yang dihasilkan oleh limbah cair industri tekstil terutama ion logam $\mathrm{As}, \mathrm{Cd}, \mathrm{Cr}$, $\mathrm{Pb}, \mathrm{Cu}$, dan $\mathrm{Zn}$. Intensitas zat warna dan kandungan ion logam pada limbah cair industri tekstil dapat dikurangi dengan cara fisika, kimia maupun biologi. Pada cara kimia, beberapa metode yang digunakan Peneliti untuk mengurangi pencemaran pada limbah industri tekstil diantaranya: koagulasi-flokulasi, oksidasi elektrokimia, adsorpsi dan filtrasi membran (Min et al., 2012). Teknologi membran dianggap cara kimia yang efektif untuk mengurangi polutan zat warna dan ion logam pada limbah. Teknologi membran memiliki beberapa keunggulan dibandingkan dengan proses yang lain, antara lain: (a) membutuhkan ruang yang kecil, (b) tekanan rendah, dan (c) selektivitas pemisahan tinggi (Barakat., 2011). Kekurangan teknologi membran antara lain: fluks dan selektifitas karena pada proses membran umumnya terjadi fenomena fluks berbanding terbalik dengan selektifitas. Semakin tinggi fluks seringkali berakibat menurunnya selektifitas dan sebaliknya, sedangkan yang diinginkan dalam proses berbasiskan membran adalah mempertinggi fluks dan selektifitas.

Pada artikel ini membran padat kitosansilika-polietilen glikol $(\mathrm{Ch} / \mathrm{Si} / \mathrm{P})$ digunakan sebagai membran pemisah zat warna Rhodamin $\mathrm{B}$, ion $\mathrm{Pb}(\mathrm{II}), \mathrm{Cu}(\mathrm{II})$, dan $\mathrm{Cd}(\mathrm{II})$ dalam limbah cair industri tekstil menggunakan metode deadend. Hasil uji kinerja membran $\mathrm{Ch} / \mathrm{Si} / \mathrm{P}$ sebagai membran pemisah zat warna Rhodamin $\mathrm{B}$, ion $\mathrm{Pb}(\mathrm{II}), \mathrm{Cu}(\mathrm{II})$, dan $\mathrm{Cd}(\mathrm{II})$ dibandingkan dengan membran komersial.

\section{METODE}

Peralatan yang diperlukan meliputi: neraca analitik dengan ketelitian 0,001 gram, $\mathrm{pH}$ meter, kertas saring Whatman 42, dan alat pendukung lain seperti botol polietilen dan peralatan gelas, Alat Sentino pump dan Spektrofotometer Ultraviolet Visible untuk menguji kadar zat warna, Spektrofotometer Serapan Atom merek Perkin Elmer untuk menguji kadar ion logam. Uji kinerja membran menggunakan alat Sentino pump yang disajikan dalam Gambar 1.

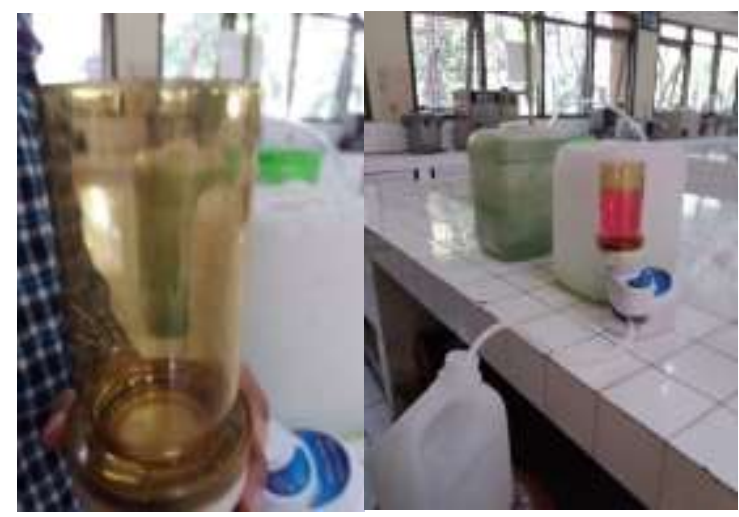

(1)

(2)

Gambar 1. Seperangkat alat uji kinerja membran (Sentino Pump)

Sampel yang digunakan adalah limbah buatan dan limbah cair industri tekstil. Variabel terkendali dalam penelitian ini: suhu dan tekanan pada ruangan yang digunakan, diameter membran 4,7 cm, ketebalan membran 0,06-0,068 $\mathrm{mm}$, konsentrasi larutan individual maupun campuran $2 \mathrm{mmol} / \mathrm{L}$ dan $\mathrm{pH}$ optimum untuk zat warna Rhodamin $\mathrm{B}=7, \mathrm{~Pb}(\mathrm{II})$ dan $\mathrm{Cu}(\mathrm{II})=6$, $\mathrm{Cd}(\mathrm{II})=5,5$ (Mahatmanti et al., 2017). Variabel terikat: selektivitas membran padat $\mathrm{Ch} / \mathrm{Si} / \mathrm{P}$ dan membran komersial terhadap ion $\mathrm{Pb}$ (II), $\mathrm{Cu}$ (II) dan $\mathrm{Cd}(\mathrm{II})$ maupun zat warna Rhodamin B yang terdapat pada limbah cair industri tekstil. Variabel bebas dalam penelitian ini adalah jenis membran.

\section{HASIL DAN PEMBAHASAN}

\section{Karakteristik membran padat $\mathrm{Ch} / \mathrm{Si} / \mathbf{P}$}

Uji kestabilan termal menggunakan
Diferensial Scanning Calorimetry (DSC) 
diperoleh data glass transition temperature $\left(T_{g}\right)$. Hasil uji $T_{g}$ merupakan topik yang masih menjadi kontroversi (He et al., 2009). Alasan utamanya adalah sifat alami dari kitosan (seperti kristalinitas, berat molekul, derajad deasetilasi) serta sumber kitosan dan metode ekstraksi kitosan berpengaruh pada nilai $T_{g}$ (MartinezCamacho et al., 2010). Kitosan memiliki nilai $\mathrm{T}_{g}$ yang tidak jelas, tetapi beberapa Peneliti memperoleh nilai $\mathrm{T}_{\mathrm{g}}$ kitosan berkisar 161-203 ${ }^{\circ} \mathrm{C}$. Glass transition temperature $\left(T_{g}\right)$ merupakan temperatur pada saat material bentuk amorf meleleh, sedangkan titik leleh $\left(T_{m}\right)$ merupakan temperatur pada saat material bentuk kristalin meleleh. $T_{m}$ diukur dari puncak temperatur pada saat terjadi peristiwa endotermik maupun eksotermik. Material dari logam-logam serta organik murni, tidak memiliki puncak temperatur dari peristiwa endotermik melainkan berasal dari ekstrapolasi temperatur permulaan $\left(T_{o}\right)$ dari peristiwa endotermik maupun eksotermik (Liu et al., 2014). Termogram DSC membran $\mathrm{Ch} / \mathrm{Si} / \mathrm{P}$ dibedakan menjadi 2 proses yaitu peristiwa endotermik yang terjadi pada suhu $40-140{ }^{\circ} \mathrm{C}$, dan peristiwa eksotermik yang terjadi pada suhu 250-320 ${ }^{\circ} \mathrm{C}$. Menurut Liu et al. (2014), pada proses endotermik terjadi penguapan dan penyerapan molekul-molekul air, komponen yang mudah menguap serta gugus hidrofilik. Pada proses eksotermik, terjadi degradasi dan pemecahan komponen membran. Hasil uji menggunakan DSC selengkapnya disajikan dalam Gambar 2.

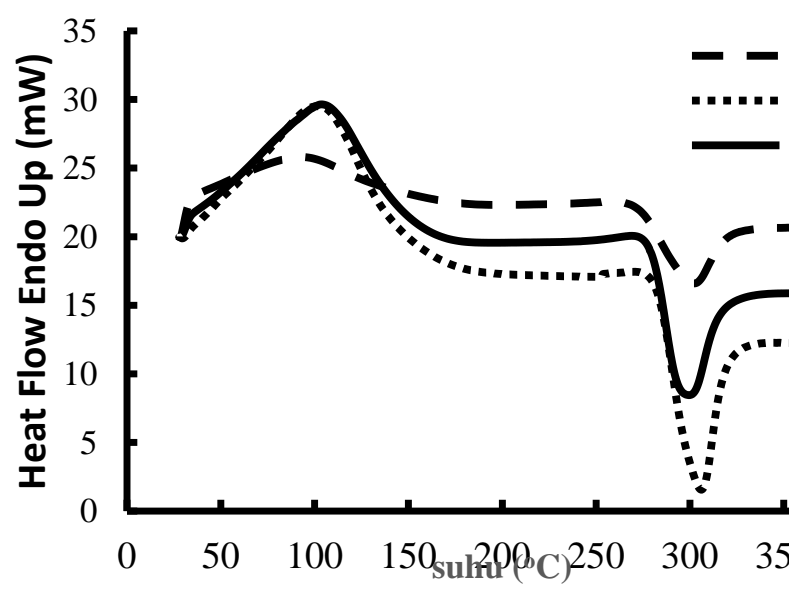

Gambar 2. Termogram DSC membran

Secara umum hasil termogram DSC pada membran, nilai $T_{o}, T_{m}$ dan $T_{g}$ pada membran $\mathrm{Ch} / \mathrm{Si}$ pada fasa eksotermik lebih besar dibandingkan dengan membran $\mathrm{Ch}$. Hal tersebut diakibatkan kenaikan jumlah ikatan hidrogen yang dibentuk antara kitosan dengan silika. Kenaikan jumlah ikatan hidrogen mengakibatkan struktur molekul menjadi stabil (Liu et al., 2014). Faktor lain yang menyebabkan nilai $T_{o}$, $T_{m}$ dan $T_{g}$ pada membran $\mathrm{Ch} / \mathrm{Si}$ lebih besar adalah berkurangnya volume bebas polimer sebagai akibat semakin banyak jumlah silika yang terjebak pada membran. Nilai $T_{o}, T_{m}$ dan $T_{g}$ pada membran $\mathrm{Ch} / \mathrm{Si} / \mathrm{P}$ pada fasa eksotermik lebih kecil dibandingkan membran $\mathrm{Ch} / \mathrm{Si}$. Hal ini diakibatkan oleh penambahan PEG pada membran terjadi secara aglomerasi dan terjebak secara fisik pada permukaan membran. Faktor lain yang menyebabkan nilai $T_{o}, T_{m}$ dan $T_{g}$ pada membran $\mathrm{Ch} / \mathrm{Si} / \mathrm{P}$ lebih kecil adalah adanya volume bebas polimer. Volume bebas polimer merupakan volume polimer yang tidak ditempati oleh molekul polimer. Semakin tinggi volume bebas, semakin banyak ruang bagi molekul untuk bergerak.

Sifat hidrofil dari membran yang dihasilkan diuji dengan cara merendam membran dalam larutan buffer dengan $\mathrm{pH} 2,0-11,0$ selama 24 jam. Hasil pengujian terhadap hidrofilisitas membran disajikan pada Gambar 3. Pada Gambar 3 dapat dilihat bahwa pada larutan yang bersifat asam kuat mengakibatkan nilai Swelling Index yang tinggi yang mengakibatkan membran larut pada $\mathrm{pH}$ 2,0 sampai $\mathrm{pH} 3,0$. Pada larutan yang bersifat asam, terjadi protonasi gugus $-\mathrm{NH}_{2}$ pada kitosan berubah menjadi $-\mathrm{NH}_{3}{ }^{+}$Pada larutan bersifat netral dan sedikit basa, nilai Swelling Index menurun dengan kenaikan $\mathrm{pH}$ larutan. Penurunan konsentrasi $\mathrm{H}^{+}$menyebabkan protonasi gugus $-\mathrm{NH}_{2}$ berkurang yang tidak terjadi pada sepanjang rantai kitosan, sehingga menyebabkan pelarut dengan mudah berdifusi pada membran (Tanuma et al., 2010). Secara umum dapat disimpulkan bahwa penambahan silika menurunkan sifat hidrofilisitas dan penambahan PEG meningkatkan sifat hidrofilisitas seiring dengan meningkatnya nilai pH. PEG merupakan polimer yang memiliki gugus - $\mathrm{OH}$ dalam jumlah cukup banyak dan bersifat hidrofil sehingga penyerapan terhadap air semakin meningkat (Salehi dan Madaeni, 2014). 


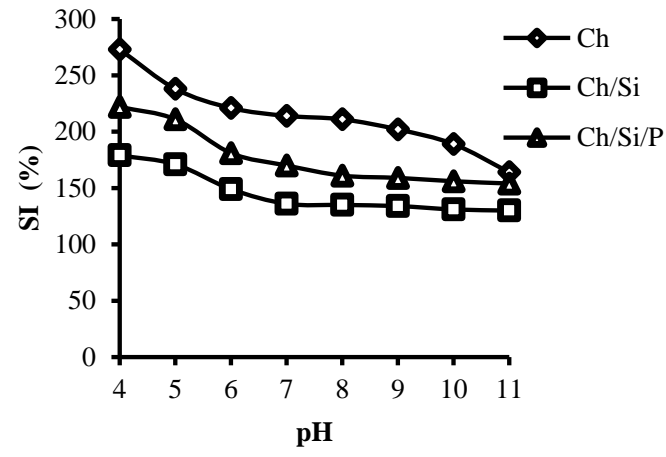

Gambar 3. Nilai Swelling Indeks (SI) pada berbagai variasi $\mathrm{pH}$ larutan pada membran

Karakteristik membran padat $\mathrm{Ch} / \mathrm{Si} / \mathrm{P}$ menunjukkan bahwa membran memiliki kestabilan termal dan tahan dalam sifat asam dibandingkan dengan membran padat kitosan (Ch) maupun membran padat kitosan-silika $(\mathrm{Ch} / \mathrm{Si})$. Membran padat $\mathrm{Ch} / \mathrm{Si} / \mathrm{P}$ memiliki kapasitas adsorpsi ion $\mathrm{Zn}$ (II) $182 \mu \mathrm{mol} / \mathrm{g}$ dan ion $\mathrm{Cd}(\mathrm{II}) \quad 106 \mu \mathrm{mol} / \mathrm{g}$ yang lebih tinggi dibandingkan membran padat $\mathrm{Ch} / \mathrm{Si}$ dan membran padat Ch (Mahatmanti et al., 2016). Oleh karena itu pada uji kinerja digunakan membran padat $\mathrm{Ch} / \mathrm{Si} / \mathrm{P}$ sebagai membran pemisah ion $\mathrm{Pb}$ (II), $\mathrm{Cu}$ (II) dan $\mathrm{Cd}(\mathrm{II})$ maupun zat warna Rhodamin B yang terdapat pada limbah cair industri tekstil yang dibandingkan dengan membran komersial.

Proses pemisahan menggunakan membran merupakan proses pemisahan pada tingkat molekuler atau partikel yang sangat kecil. Membran memiliki kemampuan memindahkan salah satu komponen lebih cepat daripada komponen yang lain berdasarkan perbedaan sifat fisik dan kimia dari membran serta komponen yang dipisahkan. Proses pemisahan oleh membran digambarkan secara sederhana pada Gambar 4.

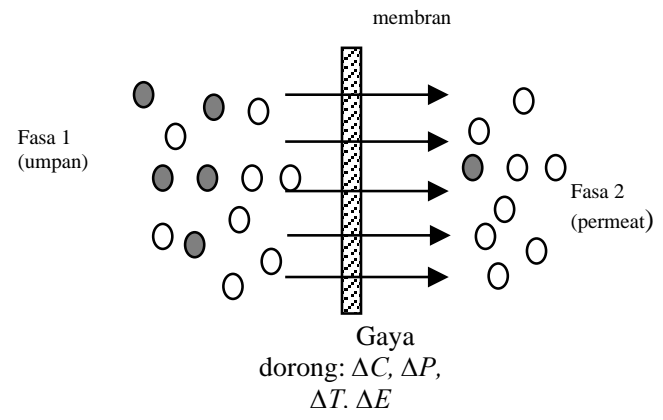

Gambar 4. Skema sederhana proses pemisahan oeh membran (Lu et al., 2007)
Uji kemampuan membran sebagai membran pemisah dilakukan untuk tiap-tiap larutan ion logam maupun campuran ion logam. Setiap pengujian dilakukan pengukuran jumlah ion logam teradsorpsi maupun ion logam terdesorpsi (terpermeasi). Selektivitas membran dinyatakan dengan koefesien rejeksi (R), merupakan fraksi konsentrasi zat telarut yang tidak menembus membran atau disebut juga dengan percent removal. Kajian percent removal pada membran $\mathrm{Ch} / \mathrm{Si} / \mathrm{P}$ maupun membran komersial terhadap zat warna Rhodamin B maupun ion $\mathrm{Pb}(\mathrm{II})$, $\mathrm{Cu}(\mathrm{II})$, dan $\mathrm{Cd}(\mathrm{II})$ disajikan pada Tabel 1 sampai 4.

Tabel 1. Kajian sifat transpor zat warna Rhodamin B

\begin{tabular}{lccl}
\hline \multirow{2}{*}{$\begin{array}{l}\text { Jenis } \\
\text { membran }\end{array}$} & \multicolumn{3}{c}{ percent removal Rhodamin B } \\
\cline { 2 - 4 } & Individual* & Campuran* & $\begin{array}{l}\text { Limbah } \\
\text { batik }\end{array}$ \\
\hline komersial & 0,4 & 12,0 & 16,0 \\
$\mathrm{Ch} / \mathrm{Si} / \mathrm{P}$ & 96,0 & 84,0 & 80,9 \\
\hline
\end{tabular}

* limbah artificial

Tabel 2. Kajian sifat transpor ion $\mathrm{Pb}(\mathrm{II})$

\begin{tabular}{lccc}
\hline \multirow{2}{*}{$\begin{array}{l}\text { Jenis } \\
\text { membran }\end{array}$} & \multicolumn{3}{c}{ percent removal ion Pb(II) } \\
\cline { 2 - 4 } & Individual* & Campuran* & $\begin{array}{l}\text { Limbah } \\
\text { batik }\end{array}$ \\
\hline komersial & 1,1 & 23,1 & 21,4 \\
$\mathrm{Ch} / \mathrm{Si} / \mathrm{P}$ & 96,5 & 85,1 & 78,9 \\
\hline
\end{tabular}

* limbah artificial

Tabel 3. Kajian sifat transpor ion $\mathrm{Cu}(\mathrm{II})$

\begin{tabular}{llll}
\hline \multirow{2}{*}{$\begin{array}{l}\text { Jenis } \\
\text { membran }\end{array}$} & \multicolumn{3}{c}{ percent removal ion Cu(II) } \\
\cline { 2 - 4 } & Individual* & Campuran* & $\begin{array}{l}\text { Limbah } \\
\text { batik }\end{array}$ \\
\hline komersial & 71,4 & 99,75 & 83,9 \\
$\mathrm{Ch} / \mathrm{Si} / \mathrm{P}$ & 9,5 & 17,5 & 11,1 \\
\hline
\end{tabular}

* limbah artificial

Tabel 4. Kajian sifat transpor ion Cd(II)

\begin{tabular}{llll}
\hline \multirow{2}{*}{$\begin{array}{l}\text { Jenis } \\
\text { membran }\end{array}$} & \multicolumn{3}{c}{ percent removal ion Cd(II) } \\
\cline { 2 - 4 } & Individual* & Campuran & $\begin{array}{l}\text { Limbah } \\
\text { batik }\end{array}$ \\
\hline komersial & 88,8 & 80,2 & 80,5 \\
$\mathrm{Ch} / \mathrm{Si} / \mathrm{P}$ & 18,4 & 20,8 & 26,1 \\
\hline
\end{tabular}

* limbah artificial

Pada kajian membran $\mathrm{Ch} / \mathrm{Si} / \mathrm{P}$ dan membran komersial sebagai membran pemisah campuran zat warna Rhodamin $\mathrm{B}$, ion $\mathrm{Pb}(\mathrm{II}), \mathrm{Cu}(\mathrm{II})$, dan $\mathrm{Cd}(\mathrm{II})$ yang terdapat pada limbah cair batik yang dilakukan menggunakan alat Sentino pump. Hasil menunjukkan bahwa selektivitas membran $\mathrm{Ch} / \mathrm{Si} / \mathrm{P}$ mengikuti urutan $\mathrm{Cu}(\mathrm{II})>\mathrm{Cd}(\mathrm{II})>$ 
$\mathrm{Pb}$ (II) > Rhodamin B. Selektivitas membran komersial mengikuti urutan Rhodamin $\mathrm{B}>$ $\mathrm{Pb}$ (II) > $\mathrm{Cd}(\mathrm{II})>\mathrm{Cu}(\mathrm{II})$. Membran $\mathrm{Ch} / \mathrm{Si} / \mathrm{P}$ memiliki selektivitas terhadap ion $\mathrm{Cu}(\mathrm{II})$ lebih tinggi dibandingkan dengan membran komersial, sedangkan membran komersial memiliki selektivitas terhadap Rhodamin B lebih tinggi dibandingkan membran $\mathrm{Ch} / \mathrm{Si} / \mathrm{P}$. Hasil foto SEM digunakan untuk mengkaji interaksi ion logam pada membran $\mathrm{Ch} / \mathrm{Si} / \mathrm{P}$ dan membran komersial yang disajikan pada Gambar 5.

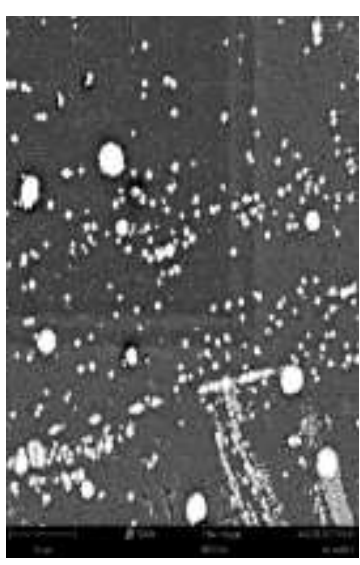

(a)

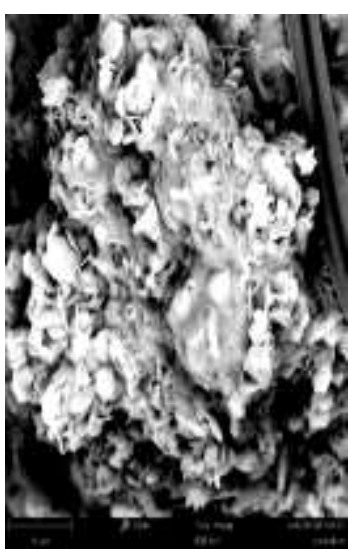

(c)

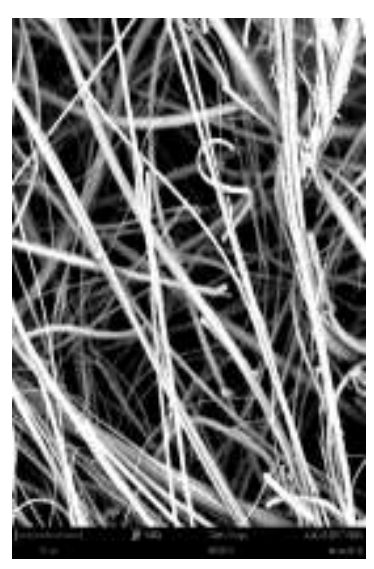

(b)

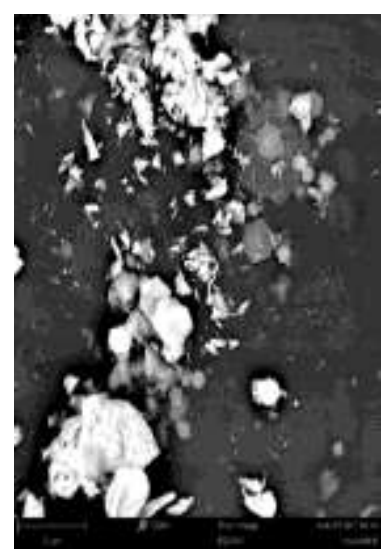

(d)
Gambar 5. (a) Membran $\mathrm{Ch} / \mathrm{Si} / \mathrm{P}$, (b) Membran komersial sebelum berinteraksi dengan limbah batik, (c) Membran $\mathrm{Ch} / \mathrm{Si} / \mathrm{P}$, (d) Membran komersial setelah berinteraksi dengan limbah batik

Permukaan membran $\mathrm{Ch} / \mathrm{Si} / \mathrm{P}$ dan membran komersial tampak tidak mulus tetapi seperti berbintik-bintik yang mengindikasikan terikatnya molekul zat warna maupun ion logam pada permukaan membran. Molekul hidrat dari ion $\mathrm{Cu}(\mathrm{II}), \mathrm{Pb}(\mathrm{II})$, dan $\mathrm{Cd}(\mathrm{II})$ terikat maupun terjebak dalam pori-pori membran. Pada permukaan membran $\mathrm{Ch} / \mathrm{Si} / \mathrm{P}$ lebih dimungkinkan tersebar gugus aktif $-\mathrm{NH}_{2}$ sehingga ion $\mathrm{Cu}(\mathrm{II})$ lebih mudah terikat pada gugus aktif $-\mathrm{NH}_{2}$ melalui pembentukan ikatan kovalen koordinasi. Permukaan membran komersial yang lebih homogen dan tertata rapi menyebabkan senyawa Rhodamin B yang memiliki ukuran besar lebih mudah melewati membran.

Proses adsorpsi maupun permeasi bergantung dan dikontrol oleh beberapa parameter seperti transfer massa, difusi larutan, reaksi kimia dan difusi partikel. Reaksi kimia yang merupakan parameter utama telah dilaporkan oleh beberapa Peneliti sebelumnya yang menyatakan bahwa gugus aktif $-\mathrm{NH}_{2}$ pada kitosan serta $-\mathrm{OH}$ yang terikat pada atom C-3 memberikan kontribusi dalam pengikatan ion logam (Madaeni, dan Salehi, 2014., Cheng et al., 2010., Kyzas et al., 2015). Mekanisme reaksi pembentukan ikatan khelat antara ion logam dengan gugus aktif, menurut Salehi et al., (2012) secara umum dapat diklasifikasikan menjadi dua model. Model yang pertama merupakan model "bridge", yaitu ion logam diikat oleh beberapa gugus aktif $-\mathrm{NH}_{2}$ dari rantai yang sama atau rantai yang berbeda melalui intramolekul atau intermolekul pembentuk senyawa kompleks. Model yang kedua merupakan kebalikan dari model pertama dan dinamakan model "pendant", yaitu ion logam terikat pada gugus $-\mathrm{NH}_{2}$ pada daerah pendant. Secara umum proses transpor ion pada membran $\mathrm{Ch} / \mathrm{Si} / \mathrm{P}$ digambarkan sebagai terjadinya pembentukan ikatan kovalen koordinasi antara ion logam dengan gugus aktif $\mathrm{NH}_{2}$

\section{KESIMPULAN}

Kajian membran $\mathrm{Ch} / \mathrm{Si} / \mathrm{P}$ dan membran komersial sebagai membran pemisah campuran zat warna Rhodamin $\mathrm{B}$, ion $\mathrm{Pb}(\mathrm{II}), \mathrm{Cu}(\mathrm{II})$, dan Cd(II) yang terdapat pada limbah cair batik dilakukan menggunakan alat Sentino pump. Hasil menunjukkan bahwa selektivitas membran $\mathrm{Ch} / \mathrm{Si} / \mathrm{P}$ mengikuti urutan $\mathrm{Cu}(\mathrm{II})>\mathrm{Cd}(\mathrm{II})>$ $\mathrm{Pb}$ (II) > Rhodamin B. Selektivitas membran komersial mengikuti urutan Rhodamin $\mathrm{B}>$ $\mathrm{Pb}(\mathrm{II})>\mathrm{Cd}(\mathrm{II})>\mathrm{Cu}(\mathrm{II})$. Membran $\mathrm{Ch} / \mathrm{Si} / \mathrm{P}$ memiliki selektivitas terhadap ion $\mathrm{Cu}(\mathrm{II})$ lebih tinggi dibandingkan dengan membran komersial, sedangkan membran komersial memiliki selektivitas terhadap Rhodamin B lebih tinggi dibandingkan membran $\mathrm{Ch} / \mathrm{Si} / \mathrm{P}$. 


\section{DAFTAR RUJUKAN}

Barakat, M.A., 2011, New trends in removing heavy metals from industrial wastewater, Arab. J. Chem., 4, 361377.

Cheng, Z., Xiaoshuai, L., Mei, H., dan Wei, M., 2010, Adsorption kinetic character of copper ions onto a modified chitosan transparent thin membrane from aqueous solution, J. Hazard. Mater., 182, 408-415.

He, L-H., Xue, R., De-bin, Y., Liu, Y., dan Song, R., 2009, Effects of blending chitosan with PEG on surface morphology, crytallization and thermal properties, Chinese J. Polym. Sci., 27(4), 501510.

Kyzas, G.Z., Panoraira, I.S., Eleni, G.P., Konstantinos, J.C., dan Dimitrios, N.B., 2015, Synthesis and adsorption application of succinyl-grafted chitosan for the simultaneous removal of zinc and cationic dye from binary hazardous mixtures., Chem. Eng. J., 259, 438-448.

Liu, M., Yibin Z., Yang Z., Chen Y., dan Shengnan C., 2014, Physicochemical, mechanical and thermal properties of chitosan films with and without sorbitol, Intern. J. of Bio. Macro., 70, 340-346.

Lu, G.Q., Diniz da Costa, J. C., Duke, M., dan Giessler S., 2007, Inorganic membranes for hydrogen production and purification: A Critical review and perspective, J. Colloid Interface Sci., 314, 589-603.

Madaeni, S.S dan E. Salehi, 2009, A new adsorption-transport and porosity combined model for passage of cations through nanofiltration membrane, J. Membr. Sci., 333, 100109.

Mahatmanti, F.W., Nuryono., Narsito, 2016, Adsorption of $\mathrm{Ca}(\mathrm{II}), \mathrm{Mg}(\mathrm{II}), \mathrm{Zn}$ (II), and $\mathrm{Cd}(\mathrm{II})$ on Chitosan Membrane Blended with Rice Hull Ash Silica and Polyethylene Glycol, Indones. J. Chem, 16(1), 45-52.

Mahatmanti, F.W., W.D.P. Rengga, E. Kusumastuti, Nuryono, 2017,
Chitosan/Silica/Polyethylene Glycol $(\mathrm{Ch} / \mathrm{Si} / \mathrm{P})$ Composites Membrane as Selective Adsorbent of Rhodamine B from Aqueeous Solution, A. J. Chem, 29(2), 283-286.

Martinez-Camacho, A.P., Cortez-Rocha, M.O., Ezquerra-Brauer, J.M., Graciano-verdugo, A.Z., Rodriguez-Felix, F., CastilloOrtega, M.M., Yepiz-Gomez, M.S., dan Plascencia-Jatomea, M, 2010, Chitosan composite films: Thermal, structural, mechanical and antifungal properties, Carbohydr. Polym., 82, 305-315.

Min, M., She, L., Hong, G., Zhu, M., Zhang, Y., dan Wang, X., 2012, Micro-nano structure poy(ether sulfones)/poly (ethyleneimine) nanofibous affinity membranes for adsorption of anionic dyes and heavy metal ions in aqueous solution, Chem. Eng. J., 197, 88-100.

Salehi, E dan S.S. Madaeni, 2014, Influence of poly(ethylene glycol) as poregenerator on morphology and performance of chitosan/poly(vinyl alcohol) membrane adsorbents, Appl. Surf. Sci., 288, 537-541.

Salehi, E., S.S. Madaeni., L. Rajabi., V. Vatanpour., A.A. Derakhsan., S. Zinadini., Sh. Ghorabi., dan H.A. Monfared, 2012, Novel chitosan/poly(vinyl) alcohol thin adsorptive membranes modified with amino functionalized multiwalled carbon nanotubes for $\mathrm{Cu}$ (II) removal from water Preparation, characterization, adsorption kinetics and thermodynamics, Sep. Purif. Technol., 89, 309-319.

Tanuma, H., Takashi, S., Kenichi, N., Tungalag, D., Koji, Y., dan Yoshio, I, 2010, Preparation and characteristic of PEG-cross-linked chitosan hydrogel films with controllable swelling and enzymatic degradation behavior, Carbohydr. Polym., 80, 260-265. 